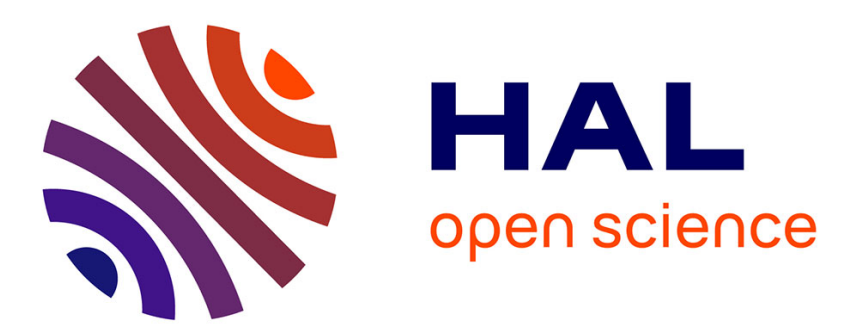

\title{
Effect of different types of fibers on the microstructure and the mechanical behavior of Ultra-High Performance Fiber-Reinforced Concretes
}

Kinda Hannawi, Hui Bian, William Prince-Agbodjan, Balaji Raghavan

\section{- To cite this version:}

Kinda Hannawi, Hui Bian, William Prince-Agbodjan, Balaji Raghavan. Effect of different types of fibers on the microstructure and the mechanical behavior of Ultra-High Performance Fiber-Reinforced Concretes. Composites Part B: Engineering, 2016, 86, pp.214-220. 10.1016/j.compositesb.2015.09.059 . hal-01225594

HAL Id: hal-01225594

https://hal-univ-rennes1.archives-ouvertes.fr/hal-01225594

Submitted on 27 Jan 2016

HAL is a multi-disciplinary open access archive for the deposit and dissemination of scientific research documents, whether they are published or not. The documents may come from teaching and research institutions in France or abroad, or from public or private research centers.
L'archive ouverte pluridisciplinaire $\mathbf{H A L}$, est destinée au dépôt et à la diffusion de documents scientifiques de niveau recherche, publiés ou non, émanant des établissements d'enseignement et de recherche français ou étrangers, des laboratoires publics ou privés. 


\title{
Effect of different types of fibers on the microstructure and the mechanical behavior of Ultra-High Performance Fiber-Reinforced Concretes
}

\author{
Kinda Hannawi*, Hui Bian, William Prince-Agbodjan, Balaji Raghavan
}

Laboratoire de Génie Civil et Génie Mécanique (LGCGM), INSA-Rennes, 20 Avenue des Buttes de Coësmes, CS 70839, 35708 Rennes Cedex 7, France

*Corresponding author. Laboratoire de Génie Civil et Génie Mécanique (LGCGM), INSA-Rennes, 20 Avenue des Buttes de Coësmes, CS 70839, 35708 Rennes Cedex 7, France

Tel.: +33 (0) 6440914 77; fax: +33 (0) 223238448

\section{Kinda.hannawi@insa-rennes.fr}

\begin{abstract}
This study investigates the effect of adding different types of fibers on the microstructure and the mechanical behavior of cementitious composites, in particular on UHPC. These fibers were distinguished mainly by their differing nature (steel, mineral and synthetic), their dimensions (macroscopic or microscopic), and their mechanical properties. The microstructure of the specimens was examined by using SEM observation and by measuring the porosity, the intrinsic permeability and the P-wave velocity. The mechanical behavior under loading has been studied using a uni-axial compression test which combines the gas permeability and the acoustic emission (AE) measurement. This work focuses on the cracking process under mechanical loading. The experimental results show that the fiber has a relatively slight influence on the compressive strength and elastic modulus of concrete, except for the steel fiber which improves the strength because of its intrinsic rigidity. However, The addition of fiber significantly reduces the lateral strain at peak loading and increases the threshold of initial cracking $\left(\sigma_{k-c i}\right)$ and that of unstable cracking $\left(\sigma_{k-p i}\right)$. Therefore, the fibers clearly restrain the cracking process in concrete under the mechanic loading.
\end{abstract}

Keywords : A.fiber, B.microstructures, B.mechanical properties,D. acoustic emission, 


\section{Introduction}

The engineering characteristics of ultra high performance concretes UHPC are different from those of conventional concrete, thereby rendering UHPC extremely popular in a large variety of applications in the construction industry, in particular for high-rise buildings and longspan bridges [1,2]. In addition, UHPC possesses a uniform high density and very low impermeability, which gives it excellent resistance to aggressive environments and disintegrating agents, thus improving the durability of concrete buildings and structures $[3,4]$. While the relatively high compressive strength of UHPC is an attractive advantage; this strength works against the ductility of the concrete by causing a pronounced increase in brittleness [5]. The UHPC always possesses a steeper descending stress-strain curve in compression compared to normal strength concrete. This rapid decrease in compressive strength in the post-peak load region brings about a predominantly brittle mode of failure [6]. To improve the concrete's ductility without sacrificing its compressive strength, one popular strategy is the addition of discrete fibers as reinforcement in UHPC [7].

Over the last decade, Ultra-High Performance Fiber-Reinforced Concretes UHPFRC have become a subject of great interest for engineers, due to the fact that the fiber addition is observed to yield an improvement in various characteristics of normal ultra high performance concretes UHPC. The incorporation of fibers reduces shrinkage and cracking and also provides ductility both under tension as well as compression.

The effects of fibers on the properties of concrete are always difficult to identify due to the extreme heterogeneity of concrete. The actual fiber that must be used depends mainly on the application 
needed for the concrete. These fibers may be distinguished by their different physical or chemical properties, such as the fiber's nature (steel, mineral or synthetic), its geometry (macro fiber v.s. micro fiber), as their aspect ration $\mathrm{L} / \phi$ and their mechanical properties, etc.

Generally these different properties of fiber yield different effects when added to their respective concretes. For the microstructure of concrete, Ivan [8] indicated that the micro fiber (shorter than $0.1 \mathrm{~mm}$ ) has a more homogenous distribution in concrete, leading to a higher packing density of cement matrix. Keer [9] reported that synthetic fiber increases the permeability of concrete due to their porous interfacial transition zone (ITZ). As far as the mechanical performances of concrete are concerned, various researchers [10-13] have studied the fibers' effect on concrete under compression or tension. They have reported that the fibers increase the tensile strength of concrete, but not necessarily its compressive strength. They have also found that the macro fiber has an efficacious capacity against the macro cracking of concrete in the post-peak phase. Natarja [14] reported that fibers with a greater ratio of $\mathrm{L} / \phi$ yield a higher compressive strength in the concrete.

Zheng [15] showed that fibers with higher tensile strength and higher elastic modulus could significantly improve the mechanical performance of concrete.

In this paper we present the effect of different types of fibers on the microstructure and the mechanical behavior of Ultra High Performance Concrete -UHPC, the microstructure of the specimens was examined by using SEM observation and by measuring the porosity, the intrinsic permeability and the P-wave velocity. The mechanical behavior under loading has been studied using a uni-axial compression test which combines the gas permeability and the acoustic emission 
(AE) measurement. This work concentrates specifically on the cracking process under mechanical loading.

\section{Material and experimental techniques}

\subsection{Materials and mixtures}

The materials used in this work are: Portland cement (CEM I 52.5) with limestone filler and siliceous filler; with the mineralogical composition given in table 1 . The aggregate used is normalized silica sand having $1,730 \mathrm{~kg} / \mathrm{m}^{3}$ bulk density and 2.65 specific gravity, and a water/cement ratio of 0.27 . Six different types of fibers have been used in this study, distinguished mainly by their different nature (steel, mineral and synthetic), their different dimensions (macroscopic or microscopic) and by their mechanical properties, as given in Table 2.

Table 1: Mineralogical composition of the used cement

\begin{tabular}{cc}
\hline Phase & \% in mass \\
\hline $\mathrm{CaO}$ & 61,7 \\
$\mathrm{SiO}_{2}$ & 17,2 \\
$\mathrm{Al}_{2} \mathrm{O}_{3}$ & 5,7 \\
$\mathrm{Fe}_{2} \mathrm{O}_{3}$ & 3,9 \\
$\mathrm{MgO}$ & 0,8 \\
$\mathrm{Na}_{2} \mathrm{O}$ & 0,41 \\
$\mathrm{~K}_{2} \mathrm{O}$ & 0,77 \\
$\mathrm{SO}_{3}$ & 3,1 \\
$\mathrm{Cl}^{-}$ & 0,04 \\
\hline
\end{tabular}


Table 2: Description of the fibers used in this study.

\begin{tabular}{ccccccc}
\hline & Steel & Wollastonite & Basalt & PVA & PP-PE & Barchip \\
\hline Material & Steel & Mineral & Mineral & Synthenic & Synthenic & Synthenic \\
Geometry & Macro & Micro & Micro & Micro & Macro & Macro \\
$\mathbf{L}(\mathbf{m m})$ & 50 & 3 & 12 & 12 & 25 & 48 \\
$\boldsymbol{\phi}(\boldsymbol{\mu m})$ & 600 & 100 & 18 & 100 & 324 & 1000 \\
$\boldsymbol{\rho}\left(\mathbf{k g} / \mathbf{m}^{3}\right)$ & 7800 & 3000 & 2800 & 1300 & 920 & 910 \\
$\boldsymbol{\sigma}_{\text {traction }}\left(\mathbf{G P}_{\mathbf{a}}\right)$ & $1-3$ & $2,7-4,1$ & $2,8-4,8$ & 1,23 & $0,03-0,04$ & 0,55 \\
$\mathbf{E}\left(\mathbf{G P}_{\mathbf{a}}\right)$ & 200 & $303-530$ & $86-90$ & 29,5 & $0,9-1,5$ & 6 \\
\hline
\end{tabular}

We have used Ultra High Performance Fiber Reinforced Concrete specimens in this work. Seven composite mixtures were prepared, a reference mixture without fiber UHPC and six mixtures with different types of fibers added with a fiber volume fraction of 1\% UHPFRC.

The experimental investigations were performed on cylindrical specimens (40 x 60) mm. The top surface and the lower surface of the specimens were properly polished before the test to ensure two surfaces sufficiently smooth and parallel. 3 specimens were prepared for each composite and each test in order to calculate their average

\subsection{Experimental techniques}

The microstructures of the UHPC and UHPFRC specimens were examined by using SEM observation and by measuring the porosity, the intrinsic permeability and the P-wave velocity. The mechanical behavior under uniaxial compressive stress was investigated by measuring the ultimate strength, Young modulus, deformations, permeability change, and acoustic emission (AE).

\subsubsection{Apparent porosity test}

The apparent porosity $(\mathrm{Pa})$ is identified according to RILEM recommendations 49TER [16]. The 
sample is dried during several days in order to remove any moisture from the voids. The apparent porosity is then calculated using formula (1).

$$
\Phi=\frac{\left(M_{\text {sat.air }}-M_{d}\right) \times \rho_{\text {water }}}{M_{\text {sat.air }}-M_{\text {sat.water }}}
$$

Where, $\mathrm{M}_{\text {sat..air: }}$ saturated mass in air (g) ; $\mathrm{M}_{\text {sat.water: }}$ immersed saturated mass in water (g); $\rho_{\text {Water: }}$ water density; $\mathrm{M}_{\mathrm{d}}$ : dry mass.

\subsubsection{Gas permeability measurement}

The gas permeability measurement depends on the porosity, the pore geometry, the pore tortuosity, and most importantly the pore connectivity of the material measured [17], and is an important method for characterizing the microstructure of a material. The gas used for the measurement must be inert and dry in order to avoid the interaction between the gas and the material measured, so we have chosen helium. The gas permeability calculated was based on the gas flux, which was measured when the specimen was under a constant percolating gas pressure, once steady-state gas flow was established. In this work, we assumed that a steady-state gas flow was established when the variation of outflow gas flux measured was less than $2 \%$ during a period of 10 minutes.

The gas permeability was then calculated by the Darcy relationship [18] for the laminar flow of a compressible fluid through a porous body under steady state conditions according to formula (2):

$$
K_{a}=\frac{2 \mu Q L P_{2}}{S\left(P_{1}^{2}-P_{2}^{2}\right)}
$$

Where $K_{a}\left(\mathrm{~m}^{2}\right)$ is the apparent gas permeability of the specimen; $Q(\mathrm{ml} / \mathrm{min})$ is the outflow gas flux 
measured; $P_{1}$ is the constant percolate gas pressure (we have chosen $0.6 \mathrm{Mpa}$ ); $P_{2}$ is the atmospheric pressure $\left(P_{2}=0.1 \mathrm{MPa}\right) ; \mu$ is the dynamic viscosity of helium gas $=2 \times 10^{-5} \mathrm{~Pa}$ s at 20

${ }^{\circ} \mathrm{C} ; \mathrm{S}$ is the cross sectional area of the specimen, and $L$ is the length of the specimen.

It must be noted that the apparent gas permeability depends on the specimen’s geometry and the gas pressure used, which might influence the measurement precision. In order to eliminate these influences out of our specimen, we measured the intrinsic gas permeability $\mathrm{K}_{\mathrm{v}}\left(\mathrm{m}^{2}\right)$ of specimens using the relationship proposed by Klinkenberg (3):

$$
K_{a}=K_{V}\left(1+\frac{\beta_{k}}{P_{m}}\right)
$$

Where $P_{m}$ is the average value of the gas pressure $P_{1}$ and $P_{2} ; \beta_{k}\left(P_{a}\right)$ is the Klinkenberg coefficient.

This $K_{v}$ is the limiting value of gas permeability when the Pm tends toward infinity, so like this measurement of permeability is effected by the liquid. The determination of $\mathrm{K}_{\mathrm{v}}$ consists of measuring $\mathrm{K}_{\mathrm{a}}$ at different percolate gas pressure $\left(\mathrm{P}_{1}=0.4,0.5,0.6,0.7\right.$ and $\left.0.8 \mathrm{MPa}\right)$, and plotting against the inverse of the gas pressure $\left(1 / \mathrm{P}_{\mathrm{m}}\right)$.

\subsubsection{P-wave velocity measurement}

P-wave velocity measurement is a very convenient method for the non-destructive testing of a given material [19 -21]. P-wave velocity VP is calculated using the transmission travel time of an acoustic pulse along the axial direction of the samples. The experimental setup includes a waveform generator, two piezoelectric transducers (with a resonant frequency of $500 \mathrm{kHz}$ ) mounted on the sample holder, and a numerical oscilloscope board connected to a computer. A constant pressure is 
systematically applied using a constant mass to ensure a tight contact between the concrete specimen and the transducers (Fig.1). We have chosen water as the coupling agent between the sample and the transducers in order to transmit the ultrasonic energy to the sample and also to not affect the gas permeability measurement with the use of other more viscous coupling agents. The travel time was measured using a program developed under the LABVIEW system with a resolution of $50 \mu \mathrm{s}$.

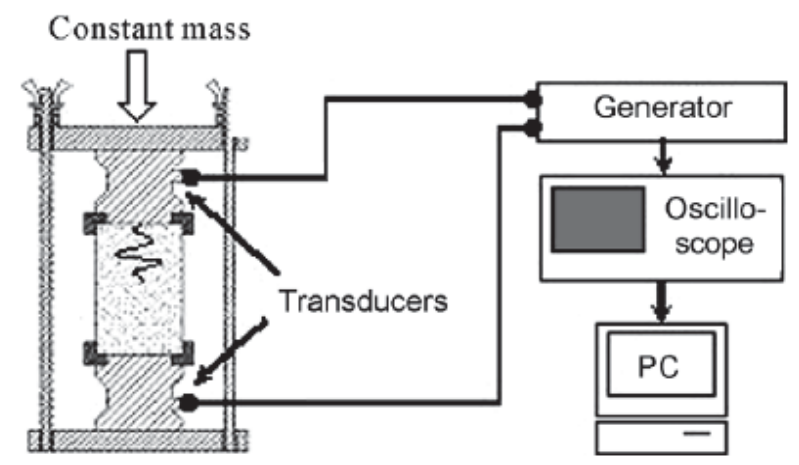

Fig. 1 : Schematic presentation of the ultrasonic device.

\subsubsection{Measurements under stress}

\section{$\underline{\text { Deformations measurement }}$}

The cylindrical concrete specimens, dimensions $40 \mathrm{~mm}$ diameter and $60 \mathrm{~mm}$ length, were loaded with a uniaxially applied stress in the direction of the longer axis of the specimens, at a loading rate of $150 \mathrm{~N} / \mathrm{s}$. The axial and circumferential strains in the sample were measured using two strain gauges directly bonded to the specimen: the first one parallel to the axis of the specimen axis and the second one along the circumferential direction. In order to calculate the volumetric strain $\left(\varepsilon_{\mathrm{v}}\right)$, the following equation has been used (4): 


$$
\varepsilon_{\mathrm{v}}=\varepsilon_{\mathrm{a}}+2 \varepsilon_{\mathrm{t}}
$$

Where $\varepsilon_{\mathrm{a}}$ and $\varepsilon_{\mathrm{t}}$ are the axial and the transverse (lateral) strains respectively.

\section{Permeability changes and AE measurement}

In this study, strains, changes in permeability, and acoustic emission (AE) were simultaneously measured during the uniaxial compressive test. To perform these measurements we have used a specific cell, a stress-flow-AE cell, that is based on a modified triaxial cell design (Fig. 2) with a special loading piston to enable the flowing of gas along the core axis during tests [20]. The percolated gas is uniformly distributed over the full face of the sample. The experiment began when all the cracks were filled with the gas and the steady-state flow was reached; that typically required between 15 minutes to an hour depending on the performance of the concrete specimen. During the experiment, once all the cracks were filled, a slight stress was found to cause an instantaneous and stable flow-rate change particularly at high gas pressure. Preliminary tests were performed to determine a proper loading rate. Since the flow rate is proportional to the apparent permeability we have used this parameter to plot the data obtained, not to mention it may be directly recorded during the test.

The AE transducer [22] was positioned on the top plate of the cell. The transducer position is not very important in our investigation. Butt [23] showed that positioning the transducer in-line with the axes of the loading piston and the core sample enables the recording of the direct $\mathrm{AE}$ waves generated in the sample, as opposed to the fully or partially reflected waves if the transducer were positioned on the side of the loading piston or on the bottom plate of the cell. The recording of 
direct $\mathrm{AE}$ waves is important for the full-waveform analysis and, in conjunction with a source transducer, for velocity and attenuation measurements. The AE signals were first amplified and then sampled at $20 \mathrm{MHz}$. In this study, analysis of the AE signals was performed using a simple approach based on estimation of cumulative events energy (event rate during a period of $100 \mathrm{~ms}$ ).

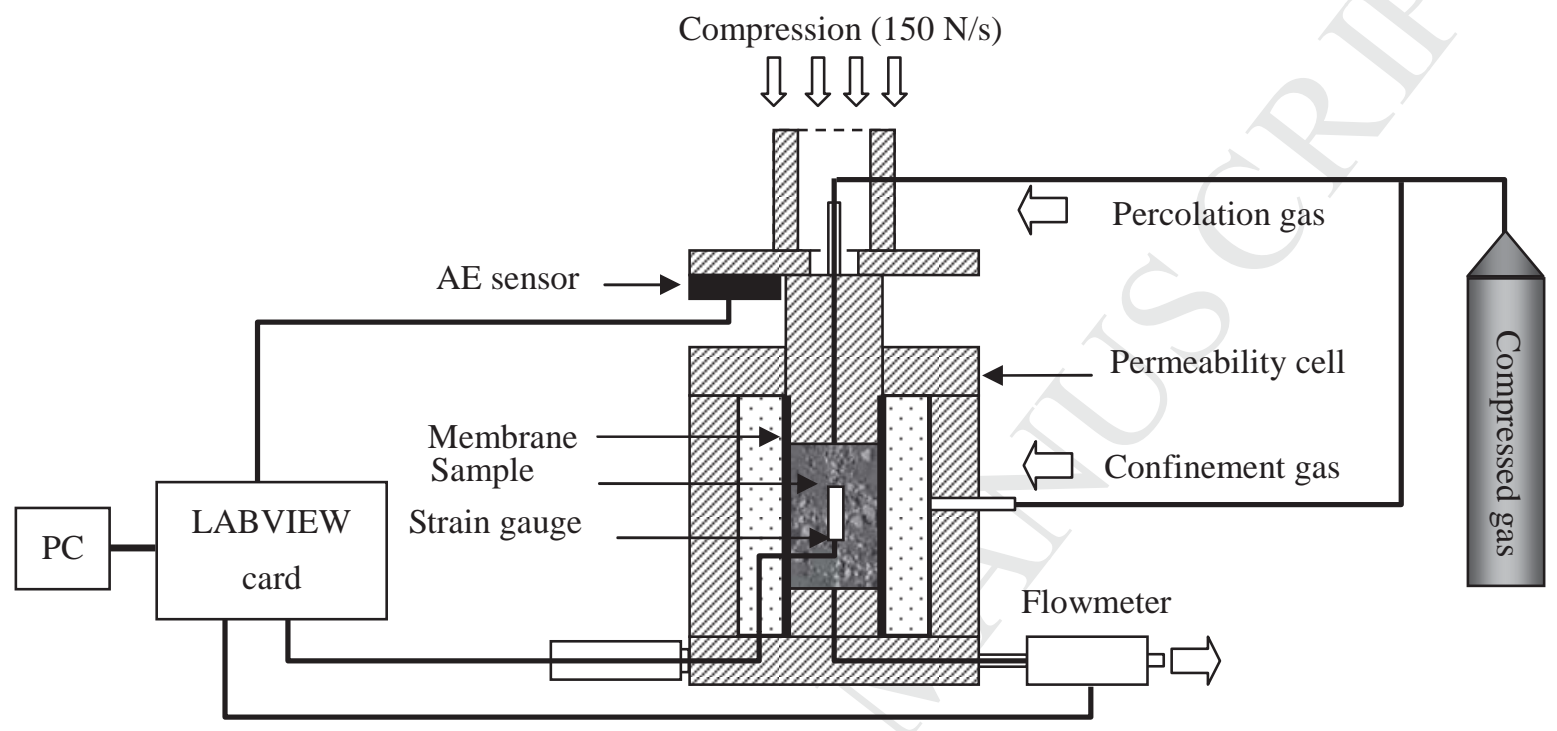

Fig. 2 : Measurement under stress.

\section{Results and Discussion:}

\subsection{SEM observation}

The SEM observation (Fig. 3) was performed after 28 days of concrete maturation. It shows that the steel fiber and the mineral fiber (Wollastonite and Basalt) have a more compact fiber/matrix interfacial zone, compared to the synthetic fiber (PVA, PP-PE and Barchip). We can explain this by understanding that the synthetic fiber being a hydrophobic material, could : (a) first and foremost restrict the water needed for cement hydration from entering the structure of the mortar specimens 
during the curing period; (b) furthermore, draw more air bubbles in the interfacial transition zone (ITZ). However the steel fiber and the mineral fiber have a surface that is more hydrophilic, and therefore, the cement paste around this fiber can properly hydrate and fill a good part of the space between the fiber and the matrix.

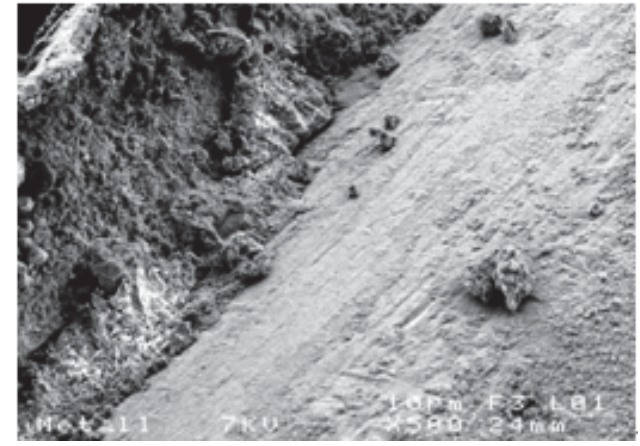

(a) Steel fiber

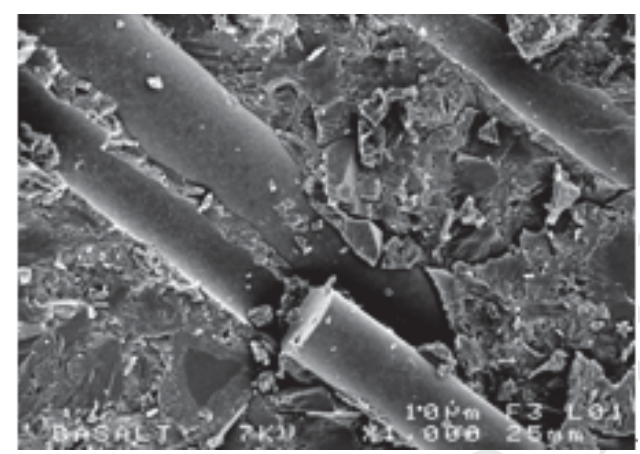

(c) Basalt

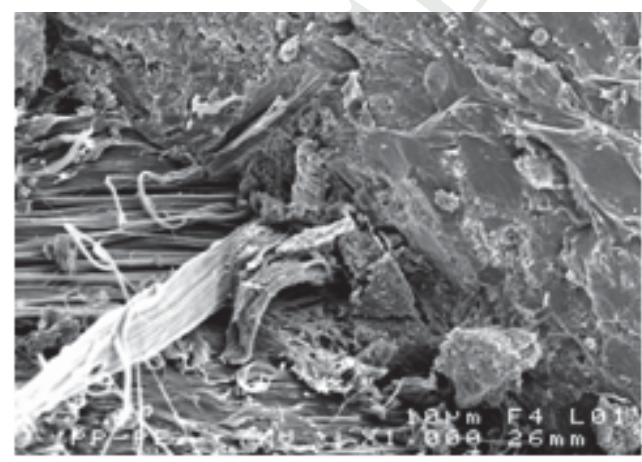

(e) PP-PE fiber

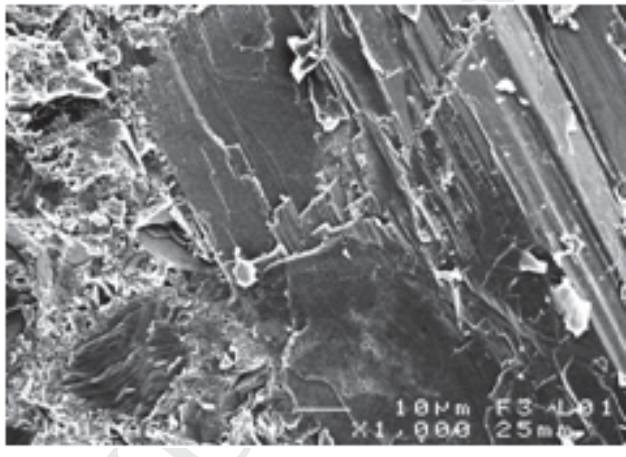

(b) Wollastonite fiber

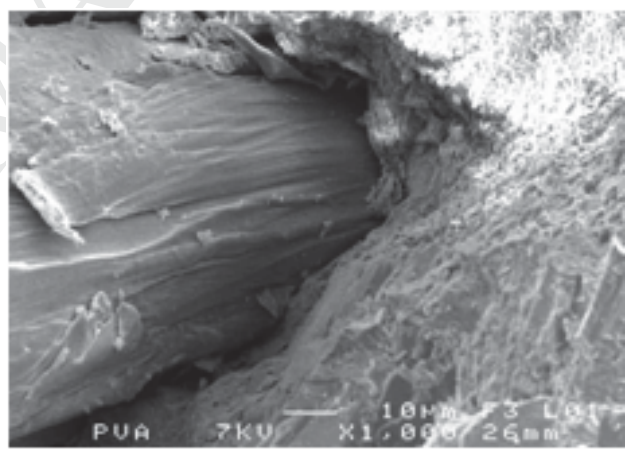

(d) PVA fiber

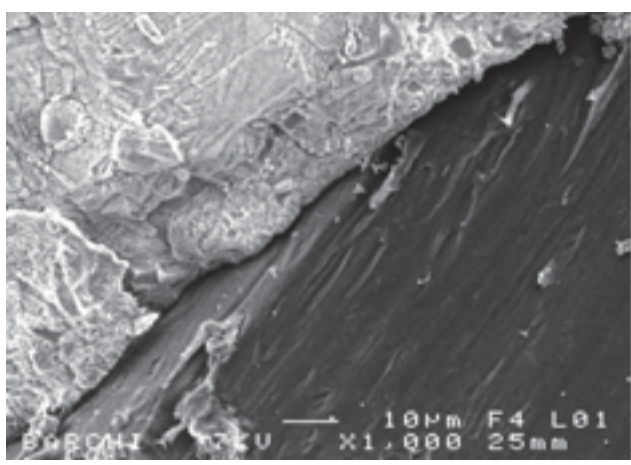

(f) Barchip fiber 
Fig. 3 : SEM observation of the fiber-matrix bond $(\times 1000)$.

\subsection{Apparent porosity}

Apparent porosity $(\Phi)$ values of the different composites are given in Table 3. We find that all

mixtures have a relatively low apparent porosity of about $10 \%$. Adding steel or mineral fibers does not have a significant influence on the porosity of mixtures in comparison with the reference concrete. However, the synthetic fibers slightly increase the porosity of composite mixtures, which can be explained by the weak adhesion between the synthetic fiber and the matrix.

Table 3: Apparent porosity of UHPC and UHPFRC specimens.

\begin{tabular}{cccccccc}
\hline & $\begin{array}{c}\text { UHPC } \\
\text { plain }\end{array}$ & $\begin{array}{c}\text { UHPFRC } \\
\text { Steel fiber }\end{array}$ & $\begin{array}{c}\text { UHPFRC } \\
\text { Wollastonite } \\
\text { fiber }\end{array}$ & $\begin{array}{c}\text { UHPFRC } \\
\text { Basalt } \\
\text { fiber }\end{array}$ & $\begin{array}{c}\text { UHPFRC } \\
\text { PVA fiber }\end{array}$ & $\begin{array}{c}\text { UHPFRC } \\
\text { PP-PE } \\
\text { fiber }\end{array}$ & $\begin{array}{c}\text { UHPFRC } \\
\text { Barchip } \\
\text { fiber }\end{array}$ \\
\hline$\Phi(\%)$ & 9.9 & 9.6 & 9.8 & 9.4 & 10.6 & 10.5 & 10.2 \\
& $( \pm 13.14 \%)$ & $( \pm 0.89 \%)$ & $( \pm 8.44 \%)$ & $( \pm 1.2 \%)$ & $( \pm 9.13 \%)$ & $( \pm 5.12 \%)$ & $( \pm 14.11 \%)$ \\
\hline
\end{tabular}

\subsection{Gas permeability}

Intrinsic gas permeability of UHPC and UHPFRC specimens is given in table 4, the experimental results reveal that the UHPC concrete specimen reinforced with synthetic fiber has a higher intrinsic gas permeability (about $10^{-17}$ ) compared to both the plain UHPC specimen as well as the UHPC with steel or mineral fiber (about $10^{-18}$ ). These results are compatible with those of apparent porosity, they may be attributed to the quality of the interface between the synthetic fibers and the cement paste. These fibers exhibit a porous interface and they induce a bridging effect which facilitates the interconnection between the pores and consequently increases the permeability. We have reproduced in Fig. 4, two images recorded by using Scanning Electron Microscope (SEM) at 
the interface between the steel fiber and the cement matrix (a), and at the interface between the synthetic fiber (PVA) and the cement matrix (b).

Table 4: Intrinsic gas permeability of UHPC and UHPFRC specimens.

\begin{tabular}{cccccccc}
\hline & $\begin{array}{c}\text { UHPC } \\
\text { plain }\end{array}$ & $\begin{array}{c}\text { UHPFRC } \\
\text { Steel fiber }\end{array}$ & $\begin{array}{c}\text { UHPFRC } \\
\text { Wollastonite } \\
\text { fiber }\end{array}$ & $\begin{array}{c}\text { UHPFRC } \\
\text { Basalt } \\
\text { fiber }\end{array}$ & $\begin{array}{c}\text { UHPFRC } \\
\text { PVA fiber }\end{array}$ & $\begin{array}{c}\text { UHPFRC } \\
\text { PP-PE } \\
\text { fiber }\end{array}$ & $\begin{array}{c}\text { UHPFRC } \\
\text { Barchip } \\
\text { fiber }\end{array}$ \\
\hline $\boldsymbol{K}_{\boldsymbol{v}}\left(\mathbf{m}^{2}\right)$ & $9.5 \times 10^{-18}$ & $7.7 \times 10^{-18}$ & $2.5 \times 10^{-18}$ & $7.5 \times 10^{-18}$ & $8 \times 10^{-17}$ & $3 \times 10^{-17}$ & $3 \times 10^{-17}$ \\
& $( \pm 11.26 \%)$ & $( \pm 0.92 \%)$ & $( \pm 7.35 \%)$ & $( \pm 0.44 \%)$ & $( \pm 10.49 \%)$ & $( \pm 4.44 \%)$ & $( \pm 17.09 \%)$ \\
\hline
\end{tabular}

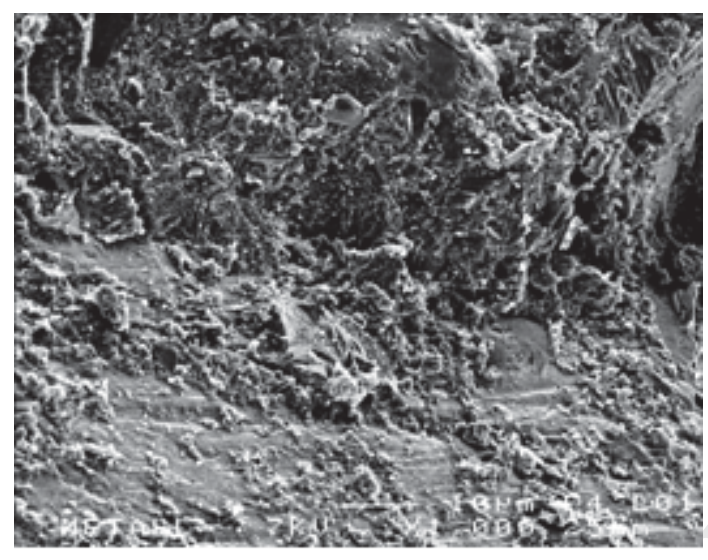

(a) Concrete with steel fiber

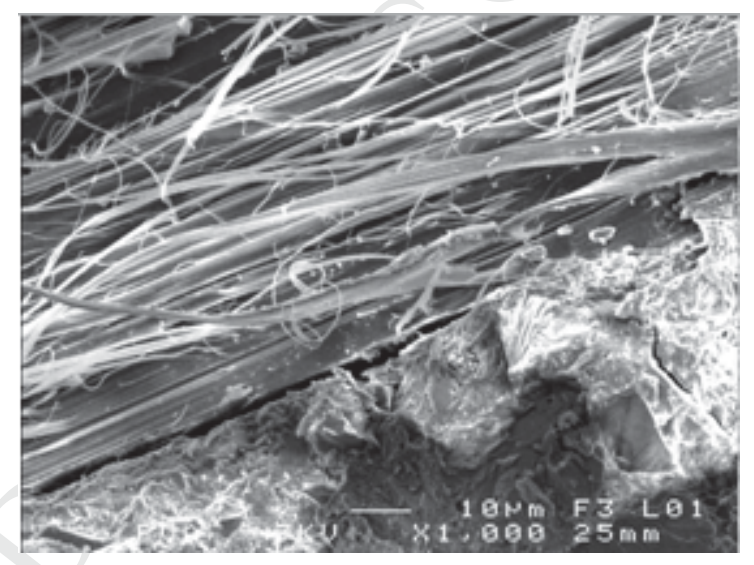

(b) Concrete with synthetic fiber (PVA)

Fig. 4: SEM observation at the fiber /cement paste interface.

\subsection{P-wave velocity}

P-wave velocity of UHPC and UHPFRC specimens has been given in table 5, we can see that the Pwave velocity of all composites is around the same order of magnitude (around $5100 \mathrm{~m} / \mathrm{s}$ ). But we can say that the UHPC with steel fiber or with the mineral fiber have a slightly higher P-wave velocity than that of the plain specimen; and except for the case of Barchip, the UHPC with synthetic fibers has a slightly lower P-wave velocity compared to the plain UHPC. This result may 
be explained by the high density of mineral and steel fiber and the low density of synthetic fiber. However, the fiber density is not the only parameter influencing the P-wave velocity. The overall properties of the mixture and particularly its porosity also affect the P-wave velocity. This can explain the high P-wave velocity of Barchip mixture which presents a slightly lower porosity compared to the other synthetic fibers.

Table 5: P-wave velocity of UHPC and UHPFRC specimens.

\begin{tabular}{cccccccc}
\hline & $\begin{array}{c}\text { UHPC } \\
\text { plain }\end{array}$ & $\begin{array}{c}\text { UHPFRC } \\
\text { Steel fiber }\end{array}$ & $\begin{array}{c}\text { UHPFRC } \\
\text { Wollastonite } \\
\text { fiber }\end{array}$ & $\begin{array}{c}\text { UHPFRC } \\
\text { Basalt } \\
\text { fiber }\end{array}$ & $\begin{array}{c}\text { UHPFRC } \\
\text { PVA fiber }\end{array}$ & $\begin{array}{c}\text { UHPFRC } \\
\text { PP-PE } \\
\text { fiber }\end{array}$ & $\begin{array}{c}\text { UHPFRC } \\
\text { Barchip } \\
\text { fiber }\end{array}$ \\
\hline $\boldsymbol{V}_{\boldsymbol{p}}(\mathbf{m} / \mathbf{s})$ & 5103 & 5177 & 5153 & 5118 & 5007 & 5088 & 5208 \\
& $( \pm 0.83 \%)$ & $( \pm 0.70 \%)$ & $( \pm 0.98 \%)$ & $( \pm 0.36 \%)$ & $( \pm 0.06 \%)$ & $( \pm 0.86 \%)$ & $( \pm 0.16 \%)$ \\
\hline
\end{tabular}

\subsection{Mechanical behavior under the compressive stress}

Permeability measurement is highly sensitive to crack development in materials because it is directly dependent on the geometry of the porous network and its interconnectivity. For this reason, it is interesting to use it to characterize the failure process in materials under mechanical test. Therefore, in this study, we have chosen to measure the deformations, the permeability changes and the acoustic emission (AE) simultaneously during the uniaxial compressive test. The results of the reference concrete are presented in the figure 5 ( $a$ and $b$ ); they reveal four phases during the specimen loading. These phases were already identified and justified by other authors [24, 27] they provide the comparison keys between the different concretes studied.

Phase 1: $\left(\sigma<\sigma_{k-s}\right)$ : phase of the closing of pre-existing cracks 
Crack closure occurs at the initial stage of loading. During this stage, the permeability decreases by a value of $\Delta K$ (from $K_{0}$ to $K_{s}$ ) this is mainly due to the decrease in the volume accessible to the fluid of percolation. Indeed, the loading causes the reduction of the micropores size and the changing of the geometry and the connectivity of cracks and their closure.

\section{Phase 2: $\left(\sigma_{\underline{k-s}}<\sigma_{k-c i}\right)$ : phase of Permeability stabilization}

During this stage, the volumetric gas flow rate remains constant during the mechanical loading. We consider that there is a combination of crack initiation, crack growth, and crack closure. The recorded acoustic emission (AE), in this phase, reveals quasi continuous bursts of microbruits of low intensity reflecting the frictions between the grains of the material and the lips of closed cracks. During this phase the longitudinal strain is linear; transverse deformation ceases to be linear and tends to increase.

\section{Phase 3: $\left(\sigma_{\mathrm{k}-\mathrm{ci}}<\sigma_{\mathrm{k}-\mathrm{pi}}\right):$ phase of Stable microcracking}

The third phase indicates an increase of the permeability (K); it corresponds to the extension of existing cracks and the creation of new microcracks; it is caused by the increase and concentration of stress. The microcracking produced during this phase generates short and isolated microbruits that become progressively more frequent as the loading increases. During this phase, the longitudinal deformation remains quasi linear and does not reflect in any way, the irreversible transformation demonstrated by the permeability change and by the acoustic signal. The transversal deformation mark a net increase of Poisson's ratio and the volumetric behavior becomes dilatant. 
Phase 4: $\left(\sigma>\sigma_{\mathrm{k}-\mathrm{p}}\right)$ : phase of unstable crack propagation:

During the last phase of the permeability increases rapidly. This increase corresponds to the development and the multiplication of cracks. The cracks propagate in an unstable manner under the effect of stress concentrations or by the coalescence of the neighboring cracks. During this phase, the intensity of the isolated noises increases along with their frequency of occurrence. The transversal strain becomes important simultaneously with the volume expansion of the specimen.

(a)

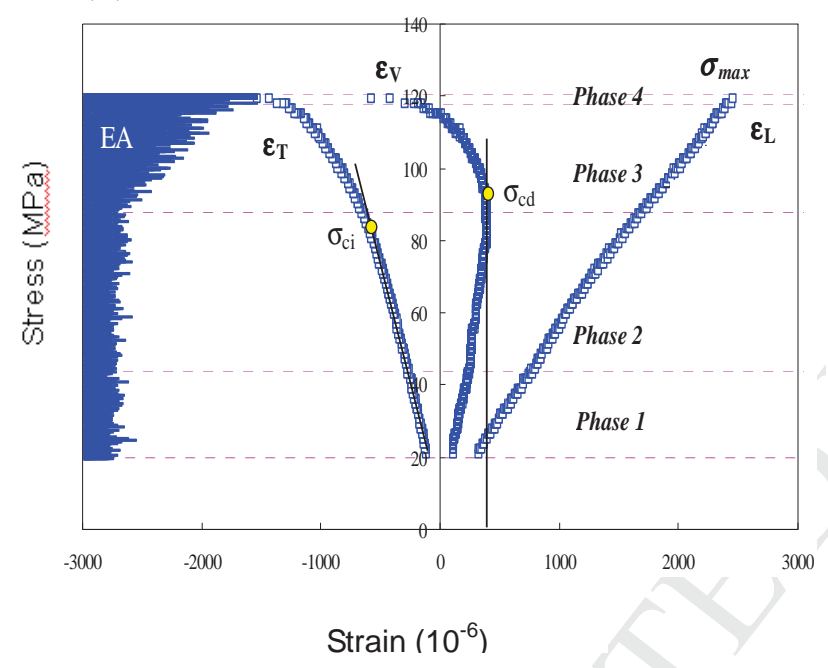

(b)

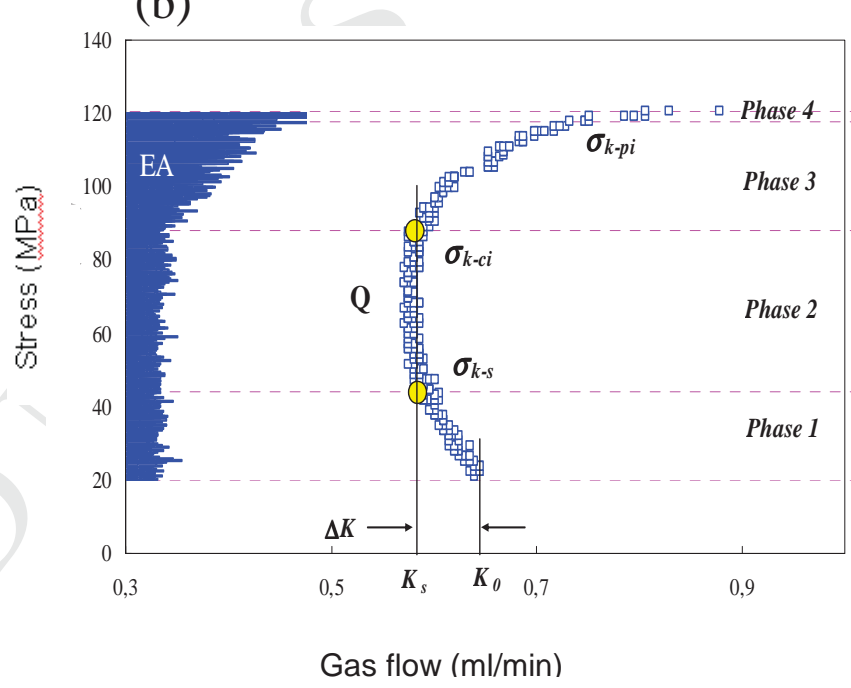

Fig. 5 : Curves of stress-strain (a) and stress-gas flow (b) of a reference specimen under the compressive stress.

The measurement under stress descripts the mechanic behaviors of specimens under the unaxial compressive loading, especially their cracking process. The results of different composites are summarized in Table 6, we find that the fiber influences very little the compressive strength and the elastic modulus of the UHPC specimens, excepting the steel fiber which has a high rigidity him-self ( an increase in compressive strength of $23 \%$ was observed in specimens containing steel fiber). 
This observation has been reported by many researchers $[10,11]$, they showed that the fiber is very efficacious in the amelioration of tensile strength of concrete, but not of compressive strength, because the fiber works in tension.

We find clearly that these fibers could decrease significantly the lateral strain of the UHPC specimens at their peak loading, because the fiber take a great part of effort in tension in the transversal direction of specimen. Only the Basalt fiber has a different behavior, it doesn’t decrease the lateral strain, but it improve the ductility of the specimen in the transversal direction (the transversal deformation of concrete containing Basalt fiber is $25 \times 10^{-4}$ versus $15 \times 10^{-4}$ of concrete without fiber), we can explain that, on the one hand, by the weak adhesion between the Basalt fibers and the matrix, on the other hand, by their greatest aspect ratio $(\mathrm{L} / \phi=667)$.

Table 6: mechanical behavior of UHPC and UHPFRC specimens under stress.

\begin{tabular}{|c|c|c|c|c|c|c|c|}
\hline & $\begin{array}{l}\text { UHPC } \\
\text { plain }\end{array}$ & $\begin{array}{l}\text { UHPFRC } \\
\text { Steel fiber }\end{array}$ & $\begin{array}{l}\text { UHPFRC } \\
\text { Wollasto- } \\
\text { nite fiber }\end{array}$ & $\begin{array}{c}\text { UHPFRC } \\
\text { Basalt } \\
\text { fiber }\end{array}$ & $\begin{array}{l}\text { UHPFRC } \\
\text { PVA fiber }\end{array}$ & $\begin{array}{l}\text { UHPFRC } \\
\text { PP-PE } \\
\text { fiber }\end{array}$ & $\begin{array}{c}\text { UHPFRC } \\
\text { Barchip } \\
\text { fiber }\end{array}$ \\
\hline $\begin{array}{l}\text { Compressive } \\
\text { strength } \sigma_{\max } \\
\quad(\mathrm{MPa})\end{array}$ & $\begin{array}{c}141 \\
( \pm 0.3 \%)\end{array}$ & $\begin{array}{c}173,2 \\
( \pm 1.3 \%)\end{array}$ & $\begin{array}{c}145,54 \\
( \pm 1.4 \%)\end{array}$ & $\begin{array}{c}139 \\
( \pm 1.1 \%)\end{array}$ & $\begin{array}{c}137,7 \\
( \pm 3.3 \%)\end{array}$ & $\begin{array}{l}124,7 \\
( \pm 3.5 \%)\end{array}$ & $\begin{array}{c}123,39 \\
( \pm 2.1 \%)\end{array}$ \\
\hline $\begin{array}{c}\text { Elastic modulus } \\
\text { E (GPa) }\end{array}$ & $\begin{array}{c}45,3 \\
( \pm 8.4 \%)\end{array}$ & $\begin{array}{c}51,8 \\
( \pm 9.7 \%)\end{array}$ & $\begin{array}{c}47,9 \\
( \pm 14.2 \%)\end{array}$ & $\begin{array}{c}46,5 \\
( \pm 6.7 \%)\end{array}$ & $\begin{array}{c}38,8 \\
( \pm 8.1 \%)\end{array}$ & $\begin{array}{c}44,8 \\
( \pm 9.8 \%)\end{array}$ & $\begin{array}{c}41,66 \\
( \pm 5.7 \%)\end{array}$ \\
\hline $\begin{array}{l}\text { Lateral strain } \\
\text { at peak loading } \\
\qquad\left(10^{-6}\right)\end{array}$ & $\begin{array}{c}1446 \\
( \pm 8.9 \%)\end{array}$ & $\begin{array}{c}1079 \\
( \pm 10.1 \%)\end{array}$ & $\begin{array}{c}918 \\
( \pm 12.7 \%)\end{array}$ & $\begin{array}{c}2101 \\
( \pm 14.5 \%)\end{array}$ & $\begin{array}{c}1069 \\
( \pm 7.6 \%)\end{array}$ & $\begin{array}{c}1042 \\
( \pm 9.6 \%)\end{array}$ & $\begin{array}{c}1124 \\
\pm 8.5 \%)\end{array}$ \\
\hline $\begin{array}{l}\text { Initial cracking } \\
\text { threshold } \sigma_{\mathrm{k}-\mathrm{ci}} \\
(\mathrm{MPa})\end{array}$ & $\begin{array}{c}73,55 \\
( \pm 8.3 \%)\end{array}$ & $\begin{array}{c}115 \\
( \pm 9.1 \%)\end{array}$ & $\begin{array}{c}90,17 \\
( \pm 5.8 \%)\end{array}$ & $\begin{array}{c}72 \\
( \pm 8.6 \%)\end{array}$ & $\begin{array}{c}97,1 \\
( \pm 7.2 \%)\end{array}$ & $\begin{array}{c}83,24 \\
( \pm 11.3 \%)\end{array}$ & $\begin{array}{c}66,64 \\
( \pm 5.3 \%)\end{array}$ \\
\hline $\begin{array}{c}\text { Unsteady } \\
\text { cracking } \\
\text { threshold } \sigma_{\mathrm{k}-\mathrm{pi}} \\
(\mathrm{MPa})\end{array}$ & $\begin{array}{c}109,5 \\
( \pm 2.3 \%)\end{array}$ & $\begin{array}{c}166,3 \\
( \pm 1.0 \%)\end{array}$ & $\begin{array}{c}127,7 \\
( \pm 3.2 \%)\end{array}$ & $\begin{array}{c}124 \\
( \pm 2.0 \%)\end{array}$ & $\begin{array}{c}134,5 \\
( \pm 6.5 \%)\end{array}$ & $\begin{array}{c}106 \\
\pm 3.8 \%)\end{array}$ & $\begin{array}{c}92,9 \\
( \pm 2.6 \%)\end{array}$ \\
\hline
\end{tabular}




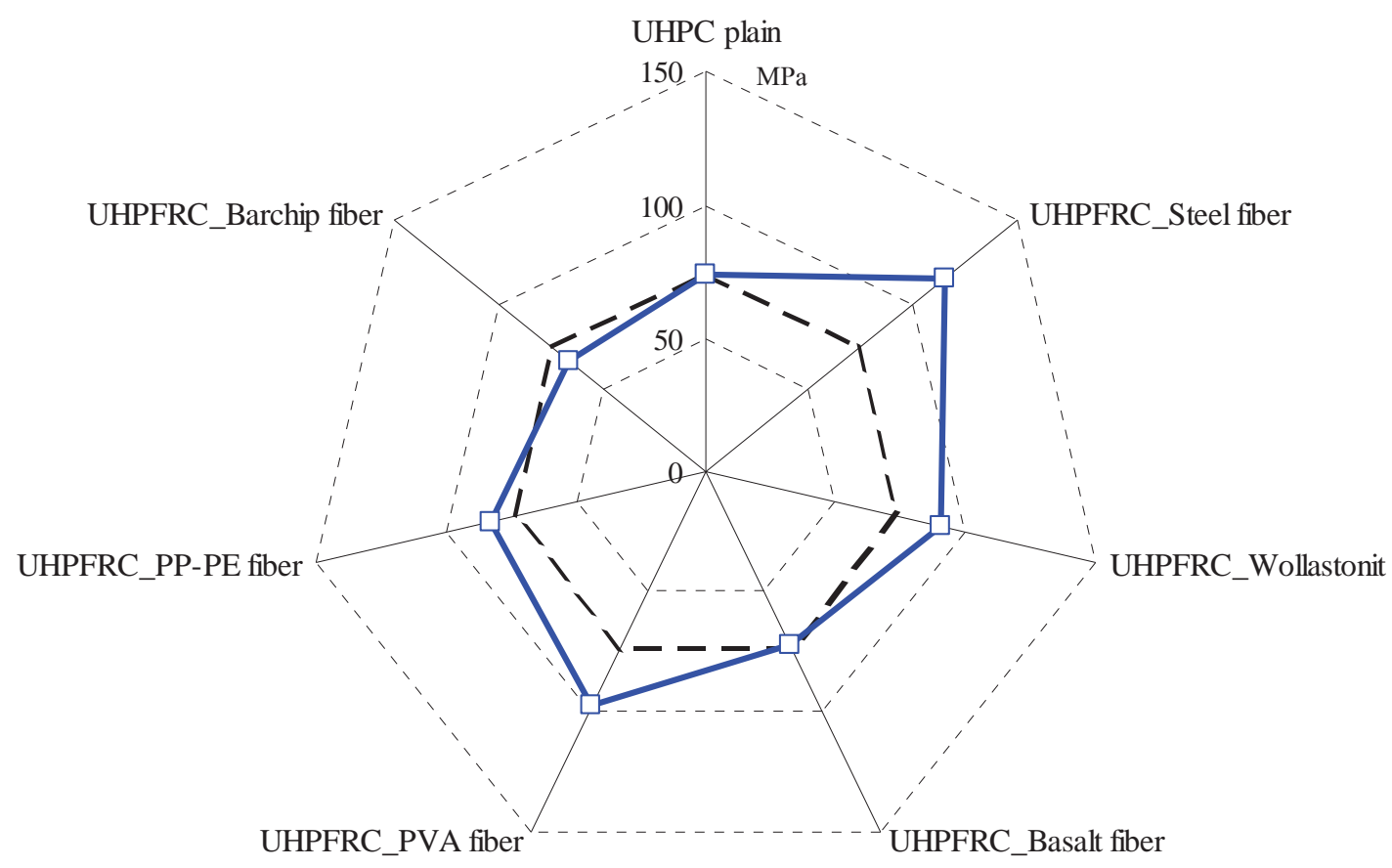

Figure 6 : Initial cracking threshold $\left(\sigma_{\mathrm{k}-\mathrm{c}}\right)$ in MPa of UHPC and UHPFRC specimens.

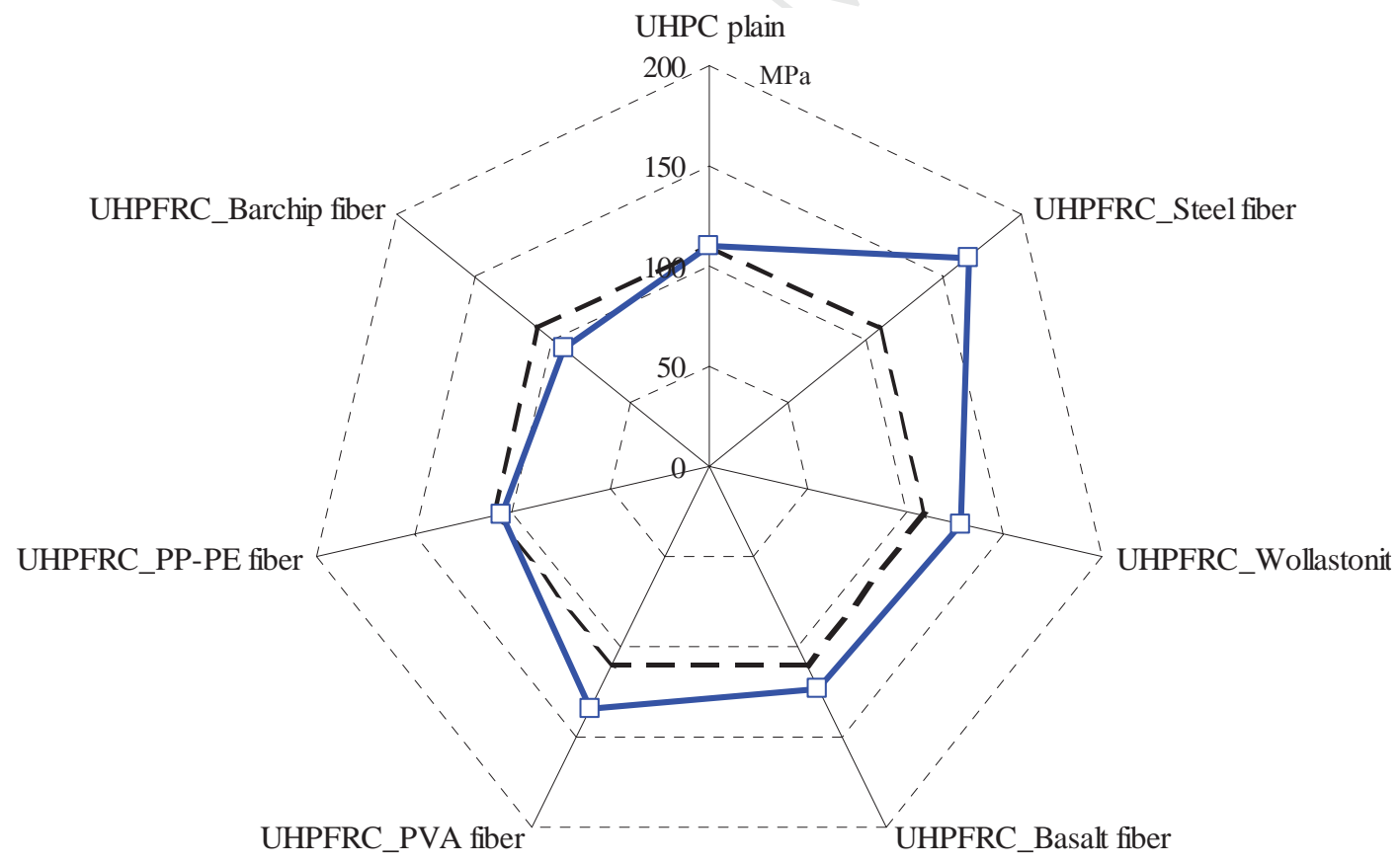

Figure 7 : Unsteady cracking threshold $\left(\sigma_{\mathrm{k}-\mathrm{pi}}\right)$ in MPa of UHPC and UHPFRC specimens. 
As shown in figures 6 and 7, we find that the use of fibers increases the threshold of initial cracking

$\left(\sigma_{\mathrm{k}-\mathrm{ci}}\right)$ and that of unstable cracking $\left(\sigma_{\mathrm{k}-\mathrm{p} i}\right)$.Therefore, the fibers clearly restrain the cracking process

in concrete under the mechanic loading, because they contribute to block the brutal propagation and the coalescence of cracks.The steel fiber is the most effective for restraining the cracking process in

UHPC specimens ( $\sigma_{\mathrm{k} \text {-ci }}$ increase $56 \%$ and $\sigma_{\mathrm{k} \text {-pi }}$ increase 52\% compared to UHPC plain), while the

barchip fibers appear to be less effective since they have a larger dimension $(\phi=1 \mathrm{~mm})$ and therefore there is a lower quantity of these fibers for the same volume percentage.

\section{Conclusion}

The work presented in this paper investigated the effect of different types of fibers on the microstructure and the mechanical behavior of Ultra High Performance Concrete UHPC, in particular on the cracking process under mechanical loading. Various types of fibers have been introduced into the UHPC at a volume fraction of $1 \%$.

The experimental results showed that

- The synthetic fiber has a porous fiber / matrix interfacial zone, compared to the steel fiber and the mineral fiber. This can be explained by the fact that the synthetic fiber is a hydrophobic material.

- The UHPC reinforced with synthetic fiber has a relatively higher porosity and intrinsic gas permeability and a relatively lower P-wave velocity compared to the plain UHPC as well as the UHPC with steel or mineral fiber.

- The study of the mechanical behavior under an unaxial compressive load showed that the fiber has 
a very slight influence on the compressive strength and the elastic modulus of the UHPC specimens, except for the steel fiber which improves the strength because of its intrinsic rigidity.

- All the fibers studied decrease the lateral strain of the UHPC specimens at their peak loading, because the fiber takes a great part of effort in tension in the transversal direction of specimen. Only the Basalt fiber has a different behavior, it doesn’t decrease the lateral strain, but it improves the ductility of the specimen in the transversal direction and this can be principally explained by their greatest aspect ratio $(\mathrm{L} / \phi=667)$.

- The use of fibers increases the threshold of initial cracking $\left(\sigma_{\mathrm{k}-\mathrm{i}}\right)$ and that of unstable cracking $\left(\sigma_{\mathrm{k}-\mathrm{pi}}\right)$.Therefore, the fibers clearly restrain the cracking process in concrete under the mechanic loading, because they contribute to block the brutal propagation and the coalescence of cracks.

\section{References}

[1] Swamy RN. High-strength concrete-material properties and structural behaviors. ACI SP-87, Detroit: American Concrete Institute; 1987. p. 110-146.

[2] Rabbat BG, Russell HG. Optimized sections for precast, prestressed bridge girders. Research and

Development Bulletin No. RD080.01E, Portland Cement Association, Skokie 1982. p. 10.

[3] Mbessa M, Péra J. Durability of high-strength concrete in ammonium sulfate solution. Cem

Concr Res 2001;31(8):1227-31.

[4] Chan SYN, Feng NQ, Tsang MKC. Durability of high-strength concrete incorporating carrier fluidifying agent. Mag Concr Res 2000;52(4):235-42. 
[5] Tasdemir C, Tasdemir MA, Lydon FD, Barr BIG. Effects of silica fume and aggregate size of the brittleness of concrete. Cem Concr Res 1996;26(1):63-8.

[6] Palmquist SM, Jansen DC. Postpeak strain-stress relationship for concrete in compression. ACI Mater J 2001;98(3):213-9.

[7] Hsu LS, Hsu T. Stress strain behavior of steel-fiber high-strength concrete under compression. ACI Struct J 1994;91(4):448-57.

[8] Ivan M. High performance hybrid fiber concrete development and utilization. Theses, University of Van Belgrado, Serbia, 2006.

[9] Keer JG. Fiber reinforced cements and concretes: recent development. Composite Structures 1992; 22(1): 61.

[10] Li FM. Fracture characterization of fiber reinforced concrete in direct uniaxial tension. These, Departement of science and technology, University of Hong Kong, Hong Kong, China, 1998.

[11] Lu XB, Cheng-Tzu TH. Behavior of high strength concrete with and without steel fiber reinforcement in triaxial compression. Cement and Concrete Research 2006;36 (9):1679-1685.

[12] Wille K, El-Tawil S, Naaman AE. Properties of strain hardening ultra high performance fiber reinforced concrete (UHP-FRC) under direct tensile loading. Cement and Concrete Composites 2014; 48:53-66.

[13] Nguyen DL, Ryu GS, Koh KT, Kim DJ. Size and geometry dependent tensile behavior of ultrahigh-performance fiber-reinforced concrete.Composites Part B 2014; 58:279-292. 
[14] Nataraja MC, Dhang N, Gupta AP. Stress-strain curves for steel-fiber reinforced concrete under compression. Cement and Concrete Composites 1999; 21 (5):383-390.

[15] Zheng ZH, Feldman D. Synthetic fibre-reinforced concrete. Progress in Polymer Science 1995;20(2): 185-210.

[16] RILEM 49TFR. Testing methods for fibre reinforced cement-based composites. RILEM Draft Recommendations. Mater Struct 1984;17:441-456.

[17] Miloud B. Permeability and porosity characteristics of steel fiber reinforced concrete. Asian Journal of Civil Engineering (Building and Housing) 2005;6 (4):317-330.

[18] ASTM Standard D4525. Standard test method for permeability of rocks by flowing air. Am Soc Test Mater 1990.

[19] Komlos K, Popovics S, Nurnbergerova T, Babal B, Popovics JS. Ultrasonic pulse velocity test of concrete-properties as specified in various standards. Cement and Concrete Composites1996;18(5): 357-364.

[20] Naffa SO, Goueygou M, Piwakowski B, Buyle-Bodin F. Detection of chemical damage concrete using ultrasound, Ultrasonics 2002; 40( 1-8) 247-251.

[21] Hauwaert AV, Thimus JF, Delannay F. Use of ultrasonics to follow crack growth, Ultrasonics 1998;36( 1-5): 209-217.

[22] Eberhardt E, Stead D, Stimpson B. Quantifying progressive pre-peak brittle fracture in rock during uniaxial compression. Int J Rock Mech Min Sci 1999;36:361-380. 
[23] Butt SD. Development of an apparatus to study the gas permeability and acoustic emission characteristics of an outburst-prone sandstone as function of stress. Int J Rock Mech Min Sci 1999;36: 1079-1085.

[24] Chaki S, Takarli M, Prince-Agbodjan W. Influence of thermal damage on physical properties of a granite rock: Porosity, permeability and ultrasonic wave evolutions. Construction and Building Materials 2008; 22( 7): 1456-1461.

[25] Takarli M, Prince-Agbodjan W, Permeability and P-wave velocity change in granitic rocks under freeze--thaw cycles. Geomechanics and Geoengineering 2007;2(3): 227-234.

[26] Takarli M, Prince-Agbodjan W, Siddique R. Damage in granite under heating/cooling cycles and water freeze-thaw condition. International Journal of Rock Mechanics and Mining Sciences 2008; 45(7):1164-1175

[27] Li FM, Fracture characterization of fiber reinforced concrete in direct uniaxial tension. These, Departement of science and technology, University of Hong Kong, Hong Kong, China, 1998. 